\title{
External Financial Auditing of Local and Regional Governments by Regional Audit Institutions in the European Union
}

\author{
Rudy Chouvel * \\ UDK $\quad 35.073 .526$ \\ $336.027 .13: 352 / 353$ \\ 339.923:061.1>(4)EU \\ Review scientific paper/pregledni znanstveni rad \\ Received/primljeno: 29.9.2016. \\ Accepted / prihvaćeno: 15.3.2017.
}

In the European Union, external financial auditing of local and regional government entities is performed according to four distinct methods. Only six states (Germany, France, Spain, Austria, Poland, and the Netherlands) resort to the use of regional audit institution (RAI). RAIs may carry out this function for local governments as a whole, or selectively. They control accounting regularity and management performance according to procedural methods that present certain analogies in all the states that have RAIs. The follow-up to RAI recommendations is of unequal scope and depends on each state. In some states, these recommendations are considered to be of imperative character, while in others their effect is considered to be achieved by the mere publication of the control report.

Keywords: external audit, financial auditing, accounts, public finance, local government, RAI, financial management

*Rudy Chouvel, PhD candidate - University of Paris I Panthéon-Sorbonne, Paris, France (doktorand na Sveučilištu Paris I Panthéon-Sorbonne, Pariz, Francuska, e-mail: rudy. chouvel@malix.univ-paris1.fr) 


\section{Introduction}

The member states of the European Union exercise external control of the accounts and financial management of their 91000 local and regional authorities in four distinct ways (Chouvel, 2017): a) a supreme audit institution (SAI) in twenty states (court of accounts or audit office), b) a regional external public finance audit institution (RAI) in half a dozen states (regional court or chamber of audit), c) a ministerial or decentralised administrative body in a dozen, and d) the private sector in a similar number of states. None of these are exclusive, because half of the states appeal to several of these institutions simultaneously, depending on the origin of the public funds involved, the nature of control exercised, or the local government in question.

However, even if every state of the EU does have an SAI, not all of them have the same status. Some have court power (France, Italy, Portugal, Greece, and Spain), while others are called courts of auditors, but do not have court power (Germany, Austria, Luxembourg, and the Netherlands). Others are organised as audit offices (Ireland, Malta, Finland, Slovenia, and Lithuania). Moreover, these SAIs either do not have the competences to control local authorities (France, Germany, Luxembourg, and Poland) or can only partially control them (for example, in Spain, Austria, the Czech Republic, and Estonia), depending on the nature of the local authorities or the public funds in question.

Public bodies also exercise external control of local authorities in a dozen EU member states. The statutes of these bodies are varied and they may be constructed as: an audit committee (the Netherlands, Sweden, Ireland Finland, and Denmark), a public institution (Germany, Belgium, and the Czech Republic), a ministerial administrative service (Luxembourg, Belgium, and Ireland), or even a local level institution (Lithuania). These bodies intervene alongside other types of control (SAI, RAI, the private sector), but generally they control the financial management of municipalities. Finally, the private audit sector occupies a significant place in the external control of the local authorities of a dozen states (Chouvel, 2016a).

The contribution of accounting professionals may be important and may concern both the accounts and the financial management of local government (United Kingdom, Sweden, and Finland), but their task is generally confined to the purely financial control of all or some local authorities (Denmark, Hungary, Germany, Malta, Latvia, Italy, the Czech Republic, Finland, and France).

The control exercised by the RAI is embedded in a framework where half of the states use several of these control methods. However, it is observed 
that although the control bodies present great diversity, the objects of the control are always the accounts and/or financial management of the community. The characteristics of RAIs differ from one country to another, as well as from one region to another (within the same country). They may or may not have jurisdictional form, may hold regional or sub-regional competence, and may provide external control of all local and regional authorities that fall within the scope of their competence or ensure an audit for some authorities only.

The RAIs in Germany, Poland, the Netherlands, Spain, France, and Austria should not be subsumed under the functional division of courts of auditors, which belong to the regional level. They should be seen as fully incorporated into the structure of the SAI and not autonomous as RAIs usually are. This also holds true for twenty regional divisions of the Italian Court of Auditors, two regional divisions of the Portuguese Court of Auditors (established in Madeira and the Azores), forty-two regional chambers of the Romanian Court of Accounts, ten regional offices of the Bulgarian Court of Auditors, twenty regional offices of the Croatian Audit Office, ten regional offices of the Czech Supreme Audit Office, and for eight regional offices of the Slovak Supreme Audit Office.

The creation of RAIs was a response to several cumulative needs. Some states did not have an independent body for the external financial management control of local governments (the Netherlands and Poland), while the federal (Germany, Austria), or quasi-federal (Spain), structure of other states led to the creation of decentralised control bodies. Finally, the large number of local governments made it impossible for the Supreme Audit Institution (SAI) to control them all (France). This last factor was probably decisive, insofar as the states concerned account for two-thirds of the total number of local governments in the EU - France alone accounting for 40 percent.

The European Organization of Regional External Public Finance Audit Institutions (EURORAI) was created in 1992 with the aim of gathering together local and regional external public finance audit institutions of the European area, in the geopolitical sense (because it integrates Russian and Swiss institutions as well), or as associate members (e.g. Brazilian institutions). A specific task of the EURORAI is to promote studies of public finance audits ${ }^{1}$ and to clarify the terminology used in each country to enable the harmonisation of methods of control.

1 EURORAI produces interesting monographs: see, for example, Regional Public Sector Audit Institutions in Europe. A Comparative Study. (2004). This study, covering ten 
The presence of RAIs in more than a fifth of European Union member states therefore raises questions about the characteristics of this type of control bodies and their work. The audits carried out by RAIs in these states do not have a uniform material scope or procedures - although the same conclusion could be drawn for SAI audits or those by other bodies - even if they do share technical analogies. The paper attempts to answer two research questions:

RQ1: Could some common features that transcend the diversity of administrative situations be found between RAIs in these countries?

RQ2: Can it be concluded that beyond the common will to ensure control in order to optimize local financial management, these states - which have the largest number of municipalities - have introduced sui generis arrangements and thus defy all attempts to make comparisons and can only be studied in juxtaposition to one another? ${ }^{2}$

The analysis of the importance of the RAI in the EU, in comparative law and institutions, leads first to the examination of their scope (whether they control all or a part of local governments), as well as their composition and the rules that apply to them. Secondly, it also leads to the assessment of the content of controls that they have set up: the control of accounts, of financial management, and of the follow-up to the recommendations given by the RAI.

\section{The Scope of RAI External Audits}

Some RAIs carry out audits of the financial management and accounts of all local and regional entities, while others only perform audits of some local governments.

\subsection{The RAI Audit of all Local and Regional Entities Within its Scope}

Article 171.2 of 1997 Polish Constitution establishes that RAIs are the audit bodies of the local authorities' activities in financial matters. The Act of 7 October 1992 created regional audit chambers that may control all

countries, is largely obsolete but EURORAI periodically refreshes its theme sheets (www. EURORAI.org): they are written by financial magistrates of the country concerned.

2 On this distinction, see Revue internationale de droit compare, 4(51), 747-1071 (contributions offered on the occasion of the fiftieth anniversary of the journal). 
the local entities within their scope. They have full autonomy and are not subject to any hierarchical subordination (Kosek-Wojnar \& Surowka, 2011, p. 228; National Audit Office, 2005, p. 203; Bouhadana, 2007, p. 354). The president of the Council of Ministers appoints the president and the members of the chamber, and they form the college of the chamber. Half of the college is composed of members appointed from among the candidates whose names are submitted for the positions by the local authorities (Kosek-Wojnar \& Surowka, 2011, p. 230). The rest of the candidates put their own names forward for the positions, without sponsorship.

Their independence is guaranteed by their status, because revocation can occur only for criminal reasons (ibid). In this respect, doctrinal ambiguity remains on the independence of regional chambers. Some authors consider regional chambers to be placed "under the supervision of the Ministry of the Interior" (Hoorens, 2008, p. 532), while others insist that they are placed "under the management" (Hugues \& Wienen, 2015, n. 76), or "under the authority of the Supreme Chamber of control of regional audit chambers" (id, n. 80). Regarding the Supreme Chamber, it seems that there is some confusion between the sixteen RAIs and the SAI's sixteen regional offices provided for in the 1997 Constitution, which can effectively control the legality of government administration bodies' activity (Article 203), but are independent from the regional chambers and have no authority over them (Hoorens, 2008, p. 532). Although there is a National Council of Regional Audit Chambers - a member of EURORAI - it has no supervision powers over the chambers. At best, it serves to coordinate, statistically consolidate, and synthesise chamber reports.

Considering the "supervision" of the Ministry of the Interior, the term is inappropriate because, following a change to the Act of October 1992 (which took place in 2001), the Ministry of the Interior acquired disciplinary powers. These can either be used individually, against a member of the chamber who has broken the law exercising his or her duties or committed an offence (Kosek-Wojnar \& Surowka., 2011, p. 230), or collectively, by dissolving the college of the chamber when it breaks the law repeatedly (Thinnes, $2015 ;{ }^{3}$ Chouvel, 2015, p. 93; Eurorai, 2009, p. 76). However, this "disciplinary" prerogative does not permit the interpretation that the Polish regional audit chambers are under the "supervision" of the Ministry of the Interior, nor is it possible to question their independence in exercising their duties (Kosek-Wojnar \& Surowka, 2011, p. 230).

3 Thinnes, E. (Secretary General of EURORAI until 2015). Correspondence, 4 November 2015 . 
The Spanish Court of Auditors is responsible for local governments in five regions (Estremadura, Murcia, Cantabria, La Rioja, and, since 2015, Castilla-La Mancha). The twelve other Spanish regions have (since 1984) set up their own RAIs (Eurorai a, p. 1; Cools, 2013, n. 4). The regional parliament determines their status, number, prerogatives, and competences, which explains the wide range of members in each chamber $(20-120$ (Eurorai a, p. 9)); the appointment method of the governing bodies (majority, absolute majority, or qualified majority); and their name (President, Sindico, Sindico Mayor, or Great Counsellor). They are appointed for a period of six years (five years in the case of the Canary Islands). The president of the regional audit institution is usually appointed by the president of the autonomous region (except in Asturias, where he is designated by the regional parliament), usually after being elected by the plenary assembly of the regional audit institution (Eurorai a - annexed tables). The staff consists of controllers, control technicians, and auditing assistants (id, p. 10) ${ }^{4}$ The dualism of Spanish external control led to the creation of a coordinating committee for the Court of Auditors in 1989. Currently it is qualified for local governments in five regions and the RAIs of the other twelve and seeks to establish common criteria and control techniques. A conference of RAI presidents was created in the same spirit in 2006 (Eurorai a, p. 5; Mézard, 2012, p. 138).

Created in 1982, the French regional audit chambers saw their number reduced to twenty, following the Act of 13 December 2011 on the distribution of litigation and the reduction of certain court proceedings, and the Decree of application of 23 February 2012 (Fermaud, 2013, p. 1614). The law (Article L.212.1 of the Code of Financial Judicial Authorities (CJF)) limits the number of regional audit chambers (CRCs) to twenty. Following the Act of 16 January 2015, regarding the delimitation of regions, some of these regional entities merged and the number of CRCs declined further. Three were the object of a merger and a seat transfer following the Decree of 30 September 2015, amending the dispositions concerning the seat and the scope of regional audit chambers. The 350 magistrates of the regional audit chambers (Cour des comptes, 2015, p. 19) are recruited through the National School of Administration, in one of three ways: (1) directly, (2) by means of advertising a vacancy, or (3) by means of "tout exterieur" (appointment of servants who have not previously

\footnotetext{
${ }^{4}$ Formerly, harsh judgments might have been listed on the control carried out by the RAI in particular because of the politicisation of recruitment (Carassus \& Rigal, 1999, p. 68).
} 
worked in public service). They are appointed by decree of the President of the Republic.

The presidents of CRCs are judges in the Court of Auditors, and are appointed by decree of the President of the Republic on the recommendation of the First President of the Court of Auditors. The CRC judges are assisted by 700 officers - half of whom are verification assistants (ibid), today called financial jurisdiction auditors. CRC are competent to carry out a financial management review (Article L.211.8 CJF) of all local and regional authorities within their respective scope. This review can be conducted following a justified request of the prefect or territorial authority (Bertucci \& Doyelle, 1996, p. 995) itself (Article L.243.4 CJF).

The disproportionate number of local authorities (in particular) which may be subject to review led the CRC to set up a review framework for the greatest local authorities. The CRCs are implicitly "filtered" on the administrative clearance thresholds of local entity accounts (Mézard, 2012, p. 54): until 2012 this was 3500 inhabitants and current revenues amounting to 750000 euros. The thresholds were upgraded with the law of 13 December 2011 to 5,000 inhabitants and current revenues amounting to three million euros (encompassing approximately 2500 communities). This implicit refocusing of audits led to a de facto abandonment of the financial management review of small local authorities. According to information provided by the Court of Auditors, only 34 municipalities and public establishments for municipal cooperation under the administrative clearance scheme were the subject of a financial management review in 2010 (ibid).

\subsection{RAI Audits Limited to Certain Local Governments}

With the exception of the scope of the Austrian Court of Auditors (since 2011), each of the nine Austrian federal states (regions) has created its own regional court of auditors for the financial control of the 86 cities with a population of over 10000 inhabitants (Article 127 A-6 of the Constitution) (Cools \& Loizidou, 2011, n. 123). The first was created in 1982; the last, for the federal capital, in 2014 (Eurorai b, p. 1). A constitutional review, in 1999, sanctioned these RAIs a posteriori by providing (Article 127 c) that each region can create an institution similar to the Court of Auditors. A qualified majority in each regional parliament elects the presidents of each of the nine regional courts, for a limited period of time. Their status is subject to special regulations (e.g. ineligibility, incompatibility). 
Despite their attachment to (regional) legislative power, the prerogatives of the courts are guaranteed by each regional constitution and their independence is reflected in particular by the right to freely determine and carry out audits (id. p. 2), even if regional governments and parliaments are allowed to entrust them with specific audits (id. p. 3). The internal organisation of each court is exclusively a matter of the court itself (id. p. 4).

Germany also refers the financial control of its local units to the authorities of each of the six regions (federal states). All of them have set up a regional audit court, sometimes compared to French regional audit chambers (Allemand, 2008, p. 289; Welz, 2003, p. 40; Lövgren, 2012, n. 27), but their terms and audit procedures differ. The constitution of each region guarantees their existence, their members' independence, and their main responsibilities (Eurorai c, p. 1). The independence of the courts is linked in particular to the recognition of magistrate status of their members and the freedom to choose the audit, when it will be performed, and by whom. (id. p. 4).

The RAIs have decision-making collegial bodies, employees in charge of audits and the preparation of decisions, and administrative staff. The terms of appointment of the president differ from one region to another. In most regions the right of proposal rests with the government or head of government. In others it rests with the president of the regional parliament or the council of elders of the regional parliament. Finally, in some regions the presidents of the regional courts of audit, and sometimes vice presidents, are elected by the parliament by a two-thirds majority. The other members of the regional court are appointed by parliamentary vote (Brandenburg, Bremen, Hamburg, North Rhine-Westphalia, and Saarland), or after the approval of parliament (Saxony-Anhalt), and by the head of government (id. p. 6). In some cases, the president of the court recommends candidates - following nationwide call for applications - after a hearing by the decision-making body of the court, and the proposals are accepted by the head of the regional government (ibid). The decision-making body of the court is called, depending on the region, the college (Berlin, Brandenburg, Hamburg, and Saarland), or the senate (Hesse, Lower Saxony, and Thuringia). It includes a president, a vice president, and other specifically designated members. The number of members ranges from four (Bremen) to sixteen (Bavaria). The term of office of the president and the vice president is 12 years (Bavaria, Hesse, Mecklenburg-Vorpommern, Lower Saxony, Saxony-Anhalt, Schleswig-Holstein, and Thuringia), and they are not eligible for re-election (ibid). Collegiality is reserved for important cases; for the others, it is a small college with two or three members (ibid). 
The Land courts of audit are divided into divisions or audit areas, headed by members of the decision-making body. The first court's scope is to exercise external financial control of the region, but some courts may also be in charge of the control of municipalities, and/or Kreise. Thus, control of municipalities is entrusted to the court (Mecklenburg-Vorpommern, Rhineland-Palatinate, Saxony, Saxony-Anhalt, Schleswig-Holstein, and in the city-states of Berlin, Bremen, and Hamburg), or the president of the court (Hesse, Thuringia) (id. 2). In some cases, the regional court of audit only controls some sub-regional local governments: large cities of over 25,000 inhabitants (Saxony-Anhalt), or Kreise and cities of over 20,000 inhabitants (Schleswig-Holstein) (Mézard, 2012, p. 136).

With the exception of European funds, whose use, according to the act of 2001 on the separation of powers of local authorities, is subject to audit by the Court of Auditors, Dutch local finances are subject to external control (acts of 1992 on municipalities and provinces). The local authorities have a choice between creating a regional audit chamber - which several of them may share - and setting up another modality of control (Liouville $\&$ Torres-Pereira, 2014, p. 82). This has been possible for the municipalities since 2006 and for the provinces since 2005 (Luppi, 2007, p. 340; National Audit Office, p. 195).

Given the choice between creating an independent regional audit chamber and creating a control committee of accounts, composed of municipal councillors (or not), more than 80 percent of municipalities have chosen the latter (Mézard, 2012, p. 147). Beginning in 1997, the first independent audit institutions emerged in Rotterdam, followed by Amsterdam, Utrecht, and the Hague (Eurorai d, p. 1; Van Haaren-Dresens, 2001, p. 21). Currently, there are thirty regional audit chambers. With regard to the provinces, 11 have agreed to create four interregional audit chambers, while one province has set up its own audit chamber (Eurorai d, p. 3). These RAIs, created by the local government in question, are independent entities. The number of chamber members is determined by the local authority/authorities. The members and the president are appointed by local assembly for a term of six years (subject to renewal) and they are subject to special rules of incompatibility and ineligibility; they can only be dismissed for criminal reasons (Mézard, 2012, p. 147; Eurorai d, p. 2). The RAI freely chooses each entity it controls but a provincial or municipal council may request a check or a specific investigation be carried out (Mézard, 2012, p. 147; Eurorai d, p. 5). 


\section{The Content of RAIs' External Control}

In the European Union, financial management and account management are two constituent elements of external control. As is the case in member states that use other audit instruments, member states that use RAIs promote one or both of these elements. This ranges from exclusivity in favour of one of these elements to a gradient of intensity for the other. As to following up on these controls, the recommendations given by RAIs may be merely indicative or they may have a mandatory character, implying that their implementation calls for a follow-up.

\subsection{The Audit of Accounts and Financial Management}

Audit bodies have defined the quality standards of control at the international level. The International Organization of Supreme Audit Institutions (INTOSAI) and its European subdivision (EUROSAI) have adopted the ISSAI standards regarding audits, procedures, and methods (Pleins feux sur les ISSAI, 2013, p. 26; OCDE, 2005, p. 77). ${ }^{5}$ These implement the ISA standards $(200,210,220$, and 230) and the ISQC quality standard developed by the International Federation of Accountants (IFAC). The European Organization of Regional Audit Institutions (EURORAI) also promotes the use of ISQC and ISSAI standards by its members and ethical standards for auditors prepared by the Council of International Standards of Accounting Ethics (IESBA) (Eurorai, 2012).

In the Netherlands, accountants control and certify the financial statements of the local authorities, and regional or communal audit institutions may, paradoxically, deal with the accounting aspects of local management (Mézard, 2012, pp .131, 138; Eurorai d, p. 1; Chouvel, 2016b, p. 25). In the four major cities, the director of the municipal bureau of verification, as an accountant, certifies financial statements, even if these towns also appoint a private accountant (Eurorai d, p. 1).

The financial courts of the Netherlands place an emphasis on performance audits (Van Montfort \& Van Twist, 2006, p. 165). The audit chambers, regional or communal, or the committees, assess the quality of

${ }^{5}$ Standards are available in public finance standards, audits of financial statements, performance audits, and compliance audits. These standards inspire and structure the institutions' control practices; see, for example, Cour des comptes, chambres régionales des comptes. (2014). Recueil des normes professionnelles. p. 74. 
management, specifically in the light of the rule known as the "three Es": economy (obtaining a higher income at a lower cost), efficiency (correspondence between the objectives and the actual results), and effectiveness (proportionality between the results and the means implemented). The chambers (or control committees) also check the regularity of the different aspects of local government financial management and assess the relevance of certain public policies (Mézard, 2012, p. 147; Eurorai d, p. 4; Van Haaren-Dresens, p. 198). A study by the Ministry of the Interior noted that the chambers and audit committees had conducted audits on subsidy policies, tenders and outsourcing benefits, hiring consultants in management, project management, urban development, and privatisation (Eurorai d, p. 4). Apart from these major control areas freely chosen by the organisations, a provincial or municipal council may request a specific audit (id. 5). The Dutch Association of Chambers of Accounts and Audit Committees (NVRR), founded in 2003, publishes a manual on the auditing of local authorities and develops recommendations on this subject based on the rules of "good practice" (id. 6).

Some states grant primacy to accounting regularity compared to the qualitative aspects of financial management; however, this does not mean that the latter is never taken into account. Thus, Spain may formally practice both control of the regularity of accounts and of sound financial management, under the rule of triple E, which appears in Article 31 of the Constitution as a requirement of sound management. While in the five regions without a RAI the Court of Auditors assumes this function, in the other twelve regions a regional chamber is responsible for the audit. As EURORAI points out, audits based on the triple $\mathrm{E}$ are a new and major challenge (Eurorai a, p. 4). The Spanish public sector in particular was subjected to audits of regularity and legality, even though the law that created the Court of Auditors in 1982 highlights the importance of the criteria of efficiency and economy that must be integrated into the controls. The regulatory and procedural arsenal on financial control may be well defined and standardised (evaluation of the existing internal control system, development of ad hoc programs for each of the areas of audit), but this is not the case with triple $\mathrm{E}$ audits, whose standards and procedures have neither been consolidated nor sufficiently well accepted by a majority of professionals (ibid). Barriers of all kinds (id. p. 7) hamper performance audits, although there is broad agreement to develop controls in this direction (ibid).

Financial management auditing of local government in France (a country with more than 500,000 local representatives) is specific in that it does 
not possess the nature of court power, but is still badly seen by local politicians. If the evolution of the judicial functions of regional and territorial chambers of accounts (CRC) is mainly due to the pressure of European law, the evolution of administrative functions, and particularly financial management review, is directly inspired by purely political concerns sometimes reflecting the contradictions that may exist between national needs and local aspirations.

Originally, the law of 2 March 1982 (the Defferre Law), stipulated that the CRC must ensure a good use of funds and provided for the possibility of presenting observations on their management to the local authorities within their scope. However, in a few years its implementation by the CRC succeeded in creating a strong resentment in local officials because they did not understand, nor did they want to admit, that doubts could be cast upon their management, even if only the local executive was the recipient of these observations. Some senators even proposed that this function of the CRC be eliminated (the proposed law was tabled in 1987 by P. Séramy). The first intervention was the law of 5 January 1988 (the Galland Law), which was a compromise between the warlike intentions of elected local officials and the national need for sound management. The Galland Law substituted the concept of regular use of funds with the concept of good use. That formulation eliminated the possibility of the CRC objecting to the choices made by deliberative assemblies and local officials. However, it did not prevent the CRC from evaluating their management to ensure regular use of public funds. This would have constituted a significant restriction of the actions of the chamber, even if the law had added that the CRC may examine the financial management of local authorities and their public institutions. The "control" of financial management, even if the word did not appear in the Defferre Law, became financial management review in 1988 (Limouzin-Lamothe, 1988, p. 427; Eurorai e, p. 12; Revue française de finances publiques, 2004).

The law of 6 February 1992 (the Joxe Law) then granted permission to the prefect (upon a reasoned request), as well as to the territorial authority, the right to request a financial management review by the CRC (Bertucci \& Doyelle, p. 995). The last step is to define the scope of this management review, a process conducted according to the law of 21 December 2001, relative to the regional chamber of audit and the Court of Auditors. It provides for the review to focus on the regularity of management actions, on the economy of the means used, and the evaluation of the results achieved against the targets set by the deliberative assembly. Again, this definition of management review is the result of a compro- 
mise (Lamarque \& Miller, 2002, p. 741) that seems to comply with the International Standard on Auditing, but nevertheless allows the CRCs to continue their work in innovative directions. In 2001 the review of the regularity of financial management became a review of financial management performance.

Although this is not jurisdictional procedure, the legislator has continued to increase the procedural safeguards surrounding management review for the benefit of the auditees and third parties; these procedural safeguards could have been improved, as pointed out by an incisive Senate report (Oudin, 1998) on management review. Some recommendations in this report were included in the law of 21 December 2001. By providing an experimentation platform (open for a period of 3-5 years), for the certification of the accounts of local authorities and their groupings, Article 110 of the law of 7 April 2015 included the local public sector in the certification procedure which applied to all the accounts of the public sphere and ended the debate on the usefulness of such a procedure without solving the numerous technical issues associated with it (Doreau-Tranquard, 2012, p. 115; Chouvel, 2016b, p. 28).

The German regional courts of audit, for their part, conduct external audits under the Organic Law on Budget Principles, the budget regulations of each region, and the internal regulations of each court that codify control practices (Eurorai c, p. 4). The courts provide an audit of accounting regularity, covering both accuracy and legal compliance (id. p. 3). They also provide control of management in terms of "economicity", which is the German version of the triple E: it includes the principle of maximisation, i.e., verifying that the best result has been obtained with the funds used, and the principle of minimisation, i.e., verifying that the result has been achieved with minimal funds (ibid). Under these control activities, the courts have an advisory function whose importance should not be underestimated. The "non-independent board" is created in connection with the control procedure and aims to conduct an informal exchange of the views and proposals of the controller and the auditee. The "independent counsel" is disconnected from any control procedure, but is the result of an explicit request made by a regional parliament, a regional government, or a minister (id. p. 2). However, this additional function of the courts is left to their discretion, as they are not legally required to exercise an advisory role (id. p. 3).

The Austrian regional courts of audit have similar powers to their German counterparts (financial regularity, sincerity of the accounts, and "econo- 
micity" control), and perform them ex-post (Eurorai b, pp. 3-4). However, some of these courts have permanent power of control over large-scale construction projects called "project progress control" (id. p. 2). Still, this management control does not transgress the ex-post character of external control, because it is set up to follow the successive stages of the project, which allows for carrying out rectifications before the work is completed, if necessary (id. p. 4). Finally, the regional governments may entrust the courts with a special mission of control by order of a regional parliament, a finance committee, or the parliamentary minority (id. p. 3).

The state occupies a special place in the external control of local governments in the European Union: the bodies responsible for this, as elsewhere, control accounting regularity and good use of public funds, but also implement powers of sanction by using self-referral to exercise a preventive legality control of budget acts for which they have the power of cancellation. The Polish regional audit chambers exercise the same external control functions as other bodies responsible for this in the European Union, but they also exercise "preventive" control of legality over the budgetary and financial acts of all local governments. The power to invalidate irregular acts imposes on the regional audit chambers a hybrid status of financial jurisdiction and administrative court. Their decisions can also be appealed to administrative courts, which is unique in Europe.

Sound financial management is audited in ways inspired by the international standards adopted and diffused by the Supreme Chamber of Control, for example, in its journal Public Audit (National Audit Office, p.

I 208). When it comes to control functions delegated by the state, standards of reliability, efficiency, and opportunity (Doric \& Smith, 2002, n. 45) are applied. The mission that observers see as fundamental is that of financial management auditing (Kosek-Wojnar \& Surowka, 2011, p. 230). It includes the procedure of the budget vote, the budget itself, the discharge, the commitments that impact the debt, grants, local taxes (ibid) and resolutions and orders of the authorities (deliberations and decisions) in the financial area (id. p 231). Since the new law on public finances came into force in 2010 it has also included the resolutions regarding the multi-year budget forecast (id. p. 234), budget projects, the ability to finance the deficit and the debt, and the ability to repay a loan (id. p. 233). Finally, there are not many aspects of budgetary and financial management of the local government that escape the chamber's surveillance and this a priori legality control of acts is accompanied by the power of cancellation of the contested act (id. p. 232; Chmielarz-Grochal, Sulkowski \& Marczewska, 2014, p. 17). Before this invalidation, the chamber informs 
the local government of the illegality and encourages it to modify the act accordingly (COE, 1999, p. 97; Doric \& Smith, 2002, n. 45). The act is cancelled in default of modifications, but this procedure is reserved only for serious illegalities, because in case of minor irregularities the chamber only suggests the necessary changes (Doric \& Smith, 2002, n. 45). Reviews of the acts' legality are assigned to a panel of three members. In 2008, for example, the regional audit chambers examined nearly 150000 resolutions and orders of the authorities - more than 97 percent of these acts were considered legal (Kosek-Wojnar \& Surowka, 2011, p. 232). In addition to the cancellation of acts, regional chambers can also suspend the execution of a budget act: this decision may be appealed to the administrative court (COE, 1999, p. 97). Cancellation decisions are themselves subject to appeal before the administrative judge (Kosek-Wojnar \& Surowka, 2011, p. 229). This preventive control of budget acts is a legality control, which includes sound financial management, integrity, and effectiveness of spending practices (Hugues \& Wienen, n. 81). Occasionally, regional audit chambers may conduct a joint audit with the Supreme Chamber of Control. According to Article 203 of the Constitution, it is possible to control the activity of local government bodies from the perspective of legality, sound management, and probity under a cooperation agreement concluded for this purpose in February 2002 (National Audit Office, 2005, p. 206; Hoorens, 2008, p. 532; Eurorai, 2009, p. 76).

\subsection{Follow-up to the Recommendations}

Checking the accuracy of accounts has long been considered sufficient, but the legitimate curiosity of parliaments and taxpayers goes beyond this, and has extended to the financial management audit, i.e., the proper use of funds (Magnet, 1991, p. 11). The control bodies have adapted to these new missions, sometimes in advance, and had to handle, with the legislator, the consequences of spending a considerable amount of administrative energy that their controls generate. In this regard, EU member states are divided into two types: one type believes that the audit report must have an effect and that the recommendations are mandatory in nature, while the other considers their effectiveness to be ensured by the publication of the report.

The publication of the report prepared by the French regional audit chambers (Lamarque \& Miller, 2001, p. 549) has required a balance approach for a long time. Since 1990 the public nature of the final observations may have raised questions because of the provisional observations, which 
remained confidential but were submitted to a growing number of stakeholders (officers and leaders out of office, as well as third parties). In order to avoid media exploitation of the work of the chambers during elections, the law of 21 December 2001 introduced a period of neutrality - which corresponded to the practice of the different CRCs - establishing that the final observations report shall not be published or communicated to its recipients or third parties in the three months preceding the elections of the local government concerned (Article L.243.5 of the CJF). Originally reserved for the executive of the local government concerned, the observations made by the French regional audit chambers have been placed under a confidentiality regime by the Galland Act of 1988. The regime was lifted two years later by the law of 15 January 1990. This text provides that the final observations letter (today referred to as a report) produced by the chamber shall be communicated by the local executive to its deliberative assembly at its next meeting (Article L.243.5 of the CJF), whereby the observations will lose their confidentiality. Article 107 of the law of 7 August 2015 provides that the final observations report, addressed to the president of a public institution for intermunicipal cooperation, is also to be sent to the mayors of the municipalities that are members of this public institution immediately after the presentation made to its assembly (Article L.243.7.II CJF). The same Article 107 established for the first time a follow-up procedure for the definitive observations report produced by a regional audit chamber for the financial management review of a local authority. Until then, it had been purely theoretical, and the local executives concerned were not forced to take any measures, or indicate the measures taken or planned in response to the chamber's observations and recommendations. As is noted in the impact study of the law, the new text aligns these follow-up rules with those in force for the Court of Auditors: the recipients of its observations are required to provide the elements on which the presentation of the follow-up will be established. With these rules adopted with no opposition or discussion - France joined the mainstream in Europe, which requires local authorities to report the measures taken in response to a financial management audit.

The law of 7 August 2015 led France to a change of perspective because the final observations letters/reports had not previously been subject to any kind of follow-up. The new article L.243.7 of the CJF now obliges the executive of a local authority or the president of a public institution for intermunicipal cooperation with its own fiscal resources, to submit, within a year, a report on the measures taken in response to the observations of the regional audit chamber. This report is communicated to the chamber, 
which provides a synthesis of the reports received, and the president of the chamber presents the synthesis during the territorial conference of public action - a consultative body created by the law of 27 January 2014. It brings together, under the chair of the president of the regional council, representatives of different local governments and the presidents or representatives of public institutions for intermunicipal cooperation with their own fiscal resources. Each regional audit chamber shall also send this synthesis to the Court of Auditors for the presentation of the follow-up to the observations included in the annual report.

In Austria, the recipients of the reports prepared by regional audit chambers are the government and the parliament of the region, or the municipal council, but an annual report summarising all audits is also submitted to the government and the parliament of the region (Eurorai b, p. 5). Once the conclusions of the audit have been sent, the mayor must notify the supervisory authority within the following three months (Article 127 A- 6 of the Constitution) of the measures taken (Gamper \& Pernthaler, 2003, p. 58). The regional courts, however, do not have the power of injunction and the improvement proposals or savings recommendations have to be implemented by the authorities of the concerned local governments (Eurorai c, p. 3).

Besides the occasional inspection reports sent to interested parties, the German regional courts of audit synthesise all the results of their controls in an annual report (sometimes called Remarks from the Court of Audit) (id. p. 5). This is not a report of accountability, nor an activity report, and occupies an important place in the discharge procedure for the financial management of the regional government. The annual report of each German regional court of audit, addressed to the government and the parliament of each region, is then published in the form of a parliamentary publication and is presented by the court at a press conference (ibid) to make it accessible to the public. However, the individual results of the control procedures are not made public: the court alone decides on the opportunity to communicate the results to other bodies - which may have the effect of indirectly ensuring publicity. Only those conclusions of fundamental importance are communicated to the minister of finance of the region (ibid). The court cannot follow any instructions because only the controlled entities can act on the consequences of the control results (ibid). Nevertheless, when control concerns municipalities, whatever the supervisory authority, it must ensure that the issues raised in the observations are followed up on (ibid).

In the Netherlands, the chambers must, as provided by the Municipality Act of 1982, send their findings and recommendations to the services controlled (Eurorai d, p. 5). The chambers have the power to submit their 
audit reports to the various municipal councils (id. p. 2). All reports communal or provincial - must be submitted to local assemblies and their executive (id. p. 6). The chambers and the control committees publish their reports, and these are usually accompanied by a press release (ibid). In Spain, the final audit report is presented by the chamber in thirteen regions to the respective local governments and to the regional parliaments, with a copy sent to the Court of Auditors (Eurorai a, p. 6). The controlled local governments decide whether to publish the report (id. p. 7). Reports on the accounts of the autonomous communities are published in full in the official journal of the community, except in Catalonia, where only publication of the regional chamber findings is mandatory (id. p. 8). Some chambers include reports in an annual report sent to the regional parliament (Castille and Leon, and Madrid), while others send their reports in succession to the various parliaments. The chambers all subsequently publish their reports on their websites (see the publication schedule in the annexed table) (ibid). In the four regions without regional chambers, and where the Court of Auditors has jurisdiction, the publication of its local government audits is ensured by their inclusion in the annual report addressed to the parliament (National Audit Office, 2005, pp. 246-247).

Polish regional audit chambers carry out preventive legal controls of budget and financial acts of the local governments, which is why they send multiple reports, opinions, decisions, warnings, and summons to local deliberative assemblies (Kosek-Wojnar \& Surowka, 2011, p. 230). Audit reports are also sent to the prime minister and bodies that assist local authorities in case errors are found (COE, 1999, p. 97). The work of the regional audit chambers are made public indirectly, by means of an annual activity report of the regional audit chambers and a report on the budget implementation by the units of local authorities made by the National Council of Regional Audit (Kosek-Wojnar \& Surowka, 2011, p. 237).

\section{Conclusion}

The RAI control model is rare in Europe. The diversity of structures, the way they are organised, and their procedures defy classification. At most, we can see that the member states that have established RAIs are those with the largest number of local authorities, because these six countries together account for about two-thirds of the total number of local governments in the European Union. The RAI is attached to a regional territory and has more detailed knowledge of this territory than an ISC. The other states with a significant number of municipalities (Romania, Italy, and 
the Czech Republic) have opted for control by means of a supreme audit institution, which has regional structures. ${ }^{6}$

More specifically, some RAIs and states have particularly original and unusual rules in the area of financial control of European local governments. For example, the RAI of Styria is open to a referral for an audit request reasoned and signed by two percent of regional electorate (law of 7 December 1989 on the control initiative), which is relatively unique in Europe and creates a direct democratic link with this audit body. Moreover, in Austria and Poland, RAIs can control a priori, concomitantly, and a posteriori - like with the Portuguese Court of Auditors, for example - contracts of some importance signed by the local authorities, and their implementation.

Finally, regarding the texts governing the RAI, the RAIs of the six member states concerned meet the conditions described in the principles approved in 2016 by the Steering Committee of the EURORAI. These are, for example, an appropriate legal framework (principle 5), independence of chairpersons and members (principle 6), no interference by the legislative or executive authorities (principle 7), appropriate resources (principle 11), financial autonomy (principle 12), prevention of conflicts of interest (principle 14), and other principles. These "guidelines" were presented, discussed, and illustrated at a seminar organised by Lower Austria's Court of Auditors in St Pölten on 29 April 2016. As for supreme audit institutions, the institutional independence of regional audit institutions is reflected in the legal framework and in budgetary autonomy; the personal independence of their members has to be sought in the modalities of their appointment and dismissal, as well as in the applicable statutory provisions. On the other hand, the situation is more complex in the states that make use of private companies or public bodies (national or decentralised), in order to ensure external control of local and regional authorities.

\section{References}

Allemand, R. (2008). Les modalités du contrôle administratif des actes locaux dans six états de l'Union européenne [The Modalities of Administrative Control of Local Acts in Six EU Member States]. Revue française de droit administratif, (2), 287-294.

${ }^{6}$ It should be noted that in order to simplify and clarify a singularly complex administrative situation, the Walloon Government proposed, in its statement of regional policy 2009-2014, the creation of a regional audit, at least in Wallonia, but to date no action has been taken regarding this project. 
Bertucci, J. Y. \& Doyelle, A. (1996). Les demandes motivées d'examen de gestion [The Motivated Requests for Management Reviews]. Actualité juridique. Droit administrative, 995-1004.

Bouhadana, I. (2007). Pologne. In G. Orsoni (Ed.), Les finances publiques en Europe [Public Finances in Europe] (pp. 345-356). Paris: Economica.

Carassus, D. \& Rigal, J. J. (1999). Les contrôles externes des finances en Europe et en Amérique du Nord [External Financial Control in Europe and North America]. Revue française de comptabilité, 310, 67-73.

Chmielarz-Grochal, A., Sulkowski, J. \& Marczewska, B. (2014). Le pouvoir local en Pologne [Local Government in Poland]. Retrieved from www.ola-europe.com.

Chouvel, R. (2015). Le contrôle externe des comptes et de la gestion des collectivités territoriales dans les États d'Europe de l'Est de l'Union européenne [External Control of Accounts and Financial Management of Local Governments in the East European Member States of the European Union). Revue Est Europa, 83-113.

Chouvel, R. (2016a). Le secteur privé et le contrôle externe des collectivités territoriales dans l'Union européenne [The Private Sector and External Financial Control of Local Governments in the European Union]. Revue de droit international et de droit comparé, 3, 430-456.

Chouvel, R. (2016b). Le contrôle externe des comptes des collectivités territoriales dans l'Union européenne [External Auditing of Accounts of Local Authorities within the European Union: Verification and Certification]. Gestion et finances publiques, 3, 25-29.

Chouvel, R. (2017). External Local Government Financial and Performance Auditing Bodies in the European Union. In Local Autonomy in the 21th Century. Paris: LGDJ - Lextenso Editions (Manuscript submitted for publication).

Cools, M. (2013), Local and Regional Democracy in Spain. Retrieved from https:// wcd.coe.int $/$ ViewDoc.jsp?p=\&id $=2047503 \&$ Site $=C M \&$ direct $=$ true.

Cools, M. \& Loizidou, I. (2011). Local and Regional Democracy in Austria. Retrieved from https://wcd.coe.int/ViewDoc.jsp?p=\&id=1756919\&Site=COE\&direct $=$ true.

Cour de Comptes. (2015). Rapport public annuel [Annual Public Report]. (Volume No. 2). Paris: La Documentation Française.

CoE (1999). Le contrôle et l'audit de l'action des collectivités locales [Supervision and Auditing of Local Authorities' Action]. Retrieved from http://www.vie-publique.fr/documents-vp/rap_conseil_europe.pdf.

Doreau-Tranquard, M. (2012). La certification des comptes des collectivités territoriales [The Certification of Accounts of Local Governments]. Revue française de finances publiques, 119, 115-124.

Doric, M. \& Smith, K. (2002). Local and Regional Democracy in Poland: CG (9) 21 Part II. Retrieved from https://wcd.coe.int/ViewDoc.jsp?p=\&id= $887443 \&$ Site $=$ DC\&direct $=$ true.

EURORAI. (2009). Externe Regionale Finanzkontrolle in Polen. [Regional Public Sector Audit in Poland]. In Externe Finanzkontrolle in Europa: Eine vergleichende Studie [The External Financial Control in Europe: A Comparative Study]. (3rd ed., pp. 69-81). Valencia: Author. 
EURORAI. (2012). Audit Quality. Promoting and Improving Quality in the Work of Regional Audit Institutions [summary]. Vilnius, 12 October 2012. http://www. eurorai.org/eurorai/eurorai_eng.nsf/titulares/report_audit_quality/\$file/Eurorai_quality\%20guidance\%20-\%20FINAL\%20February\%202013.pdf.

EURORAI. (s.d) a. Regional Public Sector Audit in Spain. Retrieved from www. eurorai.org.

EURORAI. (s.d) b. External Public Sector Audit of the Federal States in the Republic of Austria. Retrieved from www.eurorai.org.

EURORAI. (s.d) c. External Public Sector Audit of the Länder States in the Federal Republic of Germany. Retrieved from www.eurorai.org.

EURORAI. (s.d) d. Local Government Audit in the Netherlands. Retrieved from www.eurorai.org.

EURORAI. (s.d) e. The French System of Regional Public Sector Audit. Retrieved from www.eurorai.org.

Fermaud, L. (2013). Le point final apporté ã la réforme des juridictions financiêres: Une réorganisation confirmée des siêges et ressorts des CRC [The Final Point brought to the Reform of Financial Jurisdictions: A Reorganisation of CRC Seats and Scopes]. Actualité juridique. Droit administratif, 1614-1620.

Gamper, A. \& Pernthaler, P. (2003). Les autorités locales dans le systême fédéral autrichien [Local Authorities in the Austrian Federal System]. In A. Delcamp \& J. Laughlin (eds.). La décentralisation dans les Etats de l'Union européenne. Paris: La Documentation Française.

Hoorens, D. (ed.). (2008). Les collectivités territoriales dans l'Union européenne: Organisation, compétences, finances. [Local and Regional Authorities in the European Union: Organisation, Skills, Finances]. Paris: Dexia.

Hugues, C. \& Wienen, J. (2015). Local and Regional Democracy in Poland (Report CG/2015(28)12FINAL). (Explanatory memorandum). Retrieved from https://wcd.coe.int/ViewDoc.jsp?p=\&id=2295157\&Site=COE\&BackColorInternet $=\mathrm{C} 3 \mathrm{C} 3 \mathrm{C} 3 \&$ BackColorIntranet $=\mathrm{CACC} 9 \mathrm{~A} \&$ BackColorLogged $=\mathrm{E}-$ FEA9C\&direct=true.

Kosek-Wojnar, M. \& Surowka, K. (2011). Chambres régionales des comptes et gestion financiêre des collectivités territoriales en Pologne [Regional Chambers of Accounts and Financial Management of Local and Regional Authorities in Poland]. Revue française de finances publiques, 115, 227-237.

Lamarque, D. \& Miller, G. (2001). L'accês du public aux travaux des chambres [Public Access to the Work of the Chambers]. Actualité juridique. Droit administrative, 549-558.

Lamarque, D. \& Miller, G. (2002). La loi du 21 décembre 2001 sur les chambres régionales des comptes et la Cour des comptes et ses textes d'application: Missions, compositions et procedures [The 21 December 2001 Law on the Regional Audit Chambers and the Court of Auditors and its Implementing Texts: Missions, Compositions, and Procedures]. Actualité juridique. Droit administrative, 741-747.

Limouzin-Lamothe, P. (1988). La réforme des chambres régionales des comptes [Reform of Regional Chambers of Accounts]. Actualité juridique. Droit administrative, 427-433. 
Liouville, J. P. \& Torres-Pereira, A. (2014). Local and Regional Democracy in the Netherlands. (Explanatory memorandum), Strasbourg: Council of Europe. Retrieved form www.coe.int.

Lövgren, B. M. (2012). Local and Regional Democracy in Germany (Explanatory memorandum). Retrieved from https://wcd.coe.int/ViewDoc.jsp?p=\&id= $1918543 \&$ Site $=$ COE $\&$ direct $=$ true .

Luppi, P. (2007). Pays-Bas. In G. Orsoni (ed.). Les finances publiques en Europe [Public Finances in Europe] (pp. 325-344). Paris: Economica.

Magnet, J. (1991). Classification des institutions supérieures de contrôle financier [Classification of Supreme Audit Institutions]. Revue française de finances publiques, 36, 9-12.

Mézard, J. (2012). Prendre acte de la décentralisation: Pour une rénovation indispensable des contrôles de l'état sur les collectivités territoriales [Take Note of Decentralisation: For an Essential Renovation of State Control of Local and Regional Authorities]. (Report n. 300). Senate, Paris: Schedule 4.

National Audit Office. (2005). State Audit in the European Union. Retrieved from https://www.nao.org.uk/wp-content/uploads/2005/12/State_Audit_Book.pdf.

Organisation for Economic Co-operation and Development. (2005). Atteindre l'excellence dans le travail des institutions supérieures de contrôle [Achieving Excellence in the Work of the Supreme Audit Institutions]. Documents SIGMA, No. 34, Paris: Editions OCDE. Doi: 10.1787/22204261.

Oudin, J. (1998). Chambres régionales des comptes et élus locaux: Un dialogue indispensable au service de la démocratie locale [Regional Chambers of Accounts and Local Elected Representatives: An Indispensable Dialogue in the Service of Local Democracy]. (Report n. 510). Senate, Paris: Schedule 4.

Revue française de finances publiques (2004). Le contrôle externe des chambres régionales des comptes: Actualités et perspectives [The External Audit of the Regional Chambers of Accounts: News and Perspectives]. Revue française de finances publiques, (85).

Revue internationale de la vérification des comptes publics (2013). Pleins feux sur les ISSAI [Spotlight on the ISSAI]. Revue internationale de la vérification des comptes publics $4(40)$.

Van Haaren-Dresens, I. (2001). Dualisme dans la démocratie locale aux PaysBas? [Dualism in Local Democracy in the Netherlands?]. Annuaire des collectivités locales, 21, 195-203.

Van Monfort, C. J. \& Van Twist, M. J. W. (2006). La gouvernance publique aux Pays-Bas [Public Governance in the Netherlands]. Annuaire des collectivités locales, 26, 165-181.

Welz, C. (2003). Collectivités locales en Allemagne: Entre fédéralisme et subsidiarité [Local Governments in Germany: Between Federalism and Subsidiarity]. In A. Decamp \& J. Laughlin (eds.). La décentralisation dans les états de l'Union européenne [The Decentralization in the Member States of the European Union]. Paris: La Documentation Française. 


\section{EXTERNAL FINANCIAL AUDITING OF LOCAL AND REGIONAL GOVERNMENTS BY REGIONAL AUDIT INSTITUTIONS IN THE EUROPEAN UNION}

\section{Summary}

In the European Union, external financial auditing of local and regional government entities is performed according to four distinct methods, but only six states (Germany, France, Spain, Austria, Poland, and the Netherlands) resort to using the regional audit institution (RAI), whatever its name may be (regional court/chamber of accounts). The independence of the RAI is legally enshrined, by the constitution and/or by the law, in the states concerned and is reinforced by significant financial autonomy. Their statutes place their members at a distance from any mix of political or professional genres in the exercise of their functions: this all corresponds in general with the recommendations of EURORAI. The creation of RAIs was an answer to several cumulative needs. Some states did not have an external audit body for local governments (and the multiple agencies that depend on them), such as the Netherlands or Poland. The federal (Germany, Austria) or quasi-federal (Spain) structures of other states led to the creation of decentralised audit bodies. Finally, the number of local governments was, in certain cases, too bigh be controlled by a supreme audit institution (SAI), which also provided national control missions (France). This last factor was undoubtedly decisive, because it may be observed that these six states together account for about two-thirds of the total number of local governments in the European Union. These RAIs carry out their function for local governments either as a whole, or selectively, which results in the control of the accounting regularity and of management performance, achieved according to the procedural methods that present certain analogies. The follow-up to the resulting recommendations is of unequal scope, depending on each state. Some consider the recommendations to be of an imperative character, while in others their effect is considered to be achieved by the mere publication of the control report.

Keywords: external audit, financial auditing, accounts, public finance, local government, RAI, financial management 


\section{VANJSKA FINANCIJSKA REVIZIJA JEDINICA LOKALNE I REGIONALNE SAMOUPRAVE KOJU PROVODE REGIONALNE REVIZIJSKE INSTITUCIJE U DRZ̆AVAMA EUROPSKE UNIJE}

\section{Sažetak}

U Europskoj uniji vanjska financijska revizija jedinica lokalne i regionalne samouprave provodi se primjenom četiriju različitib metoda, no samo šest država članica (Njemačka, Francuska, Španjolska, Austrija, Poljska i Nizozemska) koriste regionalne revizijske institucije (RAI-e). One se još mogu nazivati i regionalnim računovodstvenim sudovima ili komorama. Neovisnost RAI-a zajamčena je ustavom ili zakonom država koje ib koriste, a neovisnosti u prilog ide $i$ znatan stupanj njibove financijske autonomije. Statuti RAI-a propisuje zabranu bilo kakvog političkog ili profesionalnog utjecaja na članove RAI-a, što je i u skladu sa EURORAI preporukama. RAI-i su nastali kao odgovor na razlicite potrebe. U nekim zemljama, kao što su Nizozemska ili Poljska, nisu postojala vanjska revizijska tijela koja bi se bavila lokalnim samoupravim jedinicama (i brojnim agencijama koje one osnivaju). S druge strane, ustrojstvo nekib zemalja, federalno (u Njemačkoj i Austriji) ili kvazi-federalno (u Španjolskoj), rezultiralo je uspostavom decentraliziranih revizijskib tijela. Napokon, u nekim slučajevima, kao npr. u Francuskoj, radilo se o tome da vrhovna revizijska institucija (SAI) nije mogla nadzirati preveliki broj jedinica lokalne samouprave. Ovaj posljednji faktor se nesumnjivo pokazao odlučujućim prilikom uspostave RAI-a u navedenim zemaljma, budući da one zajedno obubvaćaju dvije trećine jedinica lokalnih samouprava $u$ Europske unije. RAI-i mogu provoditi reviziju jedinica lokalne samouprave u cjelini ili samo nekib njezinib tijela ili institucija. RAI-e nadziru pravilnost računovodstvenog postupanja kao i rezultata poslovanja, a prilikom provedbe nadzora koriste niz proceduralnib metoda medu kojima postoji sličnost izmedu zemalja. Po provedenom nadzoru, RAI-e izdaju preporuke, no aktivnosti koje se poduzimaju radi praćenja izvršavanja preporuka nisu ujednačene izmedu zemalja. Neke zemlje izdane preporuke smatraju obvezujućima, dok se kod drugih smatra da one svoj učinak postižu samim javnim objavlivanjem.

Ključne riječi: vanjska revizija, financijska revizija, računovodstvo, javne financije, lokalna samouprava, RAI, financijsko upravlianje 